\title{
VALIDITY OF OBVIOUSNESS IN THE PATENT PROCESS: A CASE STUDY OF AKTIEBOLAGET (LOSEC)
}

\author{
Jessica Lai*
}

\begin{abstract}
The granting of patents is qualified by the assessment of whether the said invention is obvious or involved an inventive step, and has some utility. The obviousness inquiry, based on the Windsurfing test, is a factual and objective inquiry, but its evaluative nature inherently requires some degree of subjective opinion or intuition from patent examiners and courts. The resultant uncertainty is demonstrated by the different outcomes of the Aktiebolaget cases heard around the world, where dependence on the notional person and derived expert witnesses is such that different results developed from the same facts and expert witnesses. This paper looks at the validity of the obviousness inquiry in light of these uncertainties. It concludes that invention duplication exercise evidence from the Australian Aktiebolaget case would be the most beneficial type of expert evidence for the current obviousness standard as it stands. However, it also find that obviousness may not be needed at all and that removing the inquiry may not be as detrimental as it first appears, but economic studies would be required to see its true effect.
\end{abstract}

\section{INTRODUCTION}

There is a quid pro quo in modern patent systems, whereby the patentee is given a right to exclude others from their invention in return for revealing the invention and its specifications to the public. ${ }^{1}$ The patent system is an incentive-based legal regime used to encourage the creation of something new and useful to society, ${ }^{2}$ by encouraging innovation and the advent of new

* Submitted as part of the LLB(Hons) programme at Victoria University of Wellington.

1 Pope Appliance Corporation v Spanish River Pulp \& Paper Mill Ltd (1929) 46 RPC 23, 55 (PC) Viscount Dunedin.

2 Donald S Chisum, Craig Allen Nard, Herbert F Schwartz, Pauline Newman and F Scott Kieff Principles of Patent Law (2 ed, Foundation Press, New York, 2001) 6. 
information and technology. The initial focus was on the societal benefits of the invention itself, but has shifted to the contribution of the information behind the invention. ${ }^{3}$

The awarding of an exclusive right must be justified, as it limits market competition. For this reason the patent process looks not only at novelty, but also utility and obviousness (or lack of an inventive step). Obviousness is a higher threshold than novelty, which aims to ensure that society only bestows upon the inventor such a grant if the invention and its new knowledge add significantly to the existing state of the art. The higher threshold of the obviousness standard has meant that it is often referred to as the "ultimate condition to patentability". ${ }^{4}$ But the issue of how high the threshold sits has made obviousness the "largest single cause of uncertainty about the validity of patents and hence a frequent inflator of the scale and length of patent disputes". 5

This essay will look at the validity of the obviousness step in the patent process. It begins by assessing the current obviousness standard, its justifications and its problems, as demonstrated in the Aktiebolaget cases in the United Kingdom High Court, ${ }^{6}$ the High Court of Australia and the New Zealand Court of Appeal. The New Zealand case is not directly dealt with as much, because it did not discuss obviousness in as much detail. However, the issues raised are still applicable due to the same underlying concepts being behind obviousness in all three countries. The paper then looks at earlier consultation with experts in the field as a possible solution, or whether obviousness should be removed in its entirety. It concludes that, for the current obviousness standard, evidence involving an "invention duplication exercise" is the most beneficial form of evidence, and alternatively the removal of obviousness altogether is also a possible option.

\section{OBVIOUSNESS AND ITS JUSTIFICATIONS}

The main approach of obviousness taken in the United Kingdom, and adopted by New Zealand ${ }^{7}$ and Australia is the four step analysis proposed of in Windsurfing $v$ Tabur Marine. ${ }^{8}$ The first step requires identifying the inventive concept embodied in the patent. ${ }^{9}$ The second step takes the normally skilled, but unimaginative, addressee in the art at the priority date and imputes to them

3 Ibid, 15

4 Song Huang "The Nonobviousness Requirement for Biotechnological Inventions: Resolving Uncertainty in Favor of Innovation" (2005) 21 Santa Clara Computer \& High Tech LJ 597, 597.

$5 \quad$ W R Cornish Intellectual Property (3 ed, Sweet \& Maxwell, 1996) 163.

6 Upheld by the Court of Appeal in Cairnstores Ltd v Aktiebolegat Hässle (No 2) [2002] EWCA Civ 1504.

7 Smale v North Sails Ltd [1991] 3 NZLR 19, 42 (HC) Tompkins J.

$8 \quad$ Windsurfing International Inc v Tabur Marine (Great Britain) Ltd [1985] RPC 59 (EWCA).

9 Ibid, 73 Oliver LJ for the Court. 
what was, at that date, common general knowledge in the art in question. ${ }^{10}$ In some cases, depending on how specialised the art is, the normally skilled person may be highly qualified. ${ }^{11}$ The third step is to identify what differences exist between the prior art and the alleged invention. ${ }^{12}$ The court then has to ask whether, viewed without any knowledge of the alleged invention, those differences constitute steps which would have been obvious to the skilled person or whether they require any degree of invention. ${ }^{13}$

It has been said that the Windsurfing test "merely brings us back to the phrase 'would have been obvious' and does not really help us to decide when something is obvious and when it is not." ${ }^{14}$ The test does not attempt to define the meaning of obviousness or any of its terminology, ${ }^{15}$ it merely restates and "over-elaborat[es]" the statutory requirement. ${ }^{16}$ Its value lies in allowing the question of obviousness to be answered in a structured way. ${ }^{17}$

The 1624 Statute of Monopolies is the foundation of the patent system in the United Kingdom, and subsequently in Australia and New Zealand. ${ }^{18}$ The Statute does not incorporate the idea of nonobviousness, only encapsulating "any new manufacture" or novelty and utility. ${ }^{19}$ That obviousness has come to exist despite this indicates that it must serve a different purpose to that of novelty.

10 Ibid.

11 Philip W Grubb Patents for Chemicals, Pharmaceuticals and Biotechnology (3 ed, Clarendon Press, Oxford, 1999) 59.

12 Windsurfing International Inc v Tabur Marine (Great Britain) Ltd, above n 8, 73-74 Oliver LJ for the Court.

13 Ibid, 74 Oliver LJ for the Court.

14 Grubb, above n 11, 58.

15 Andrew Griffiths "Windsurfing and the Inventive Step" (1999) 2 IPQ 160, 161.

16 Ibid, 169.

17 Paul G Cole "Inventive Step - Meaning of the EPO Problem and Solution Approach, and Implications for the United Kingdom: Part 2" (1998) 20(7) EIPR 267, 271.

18 Chisum and others, above n 2, 14 .

19 The New Zealand Patents Act 1953 and Australian Patents Act 1952 (under which Aktiebolaget were tried) therefore do not include obviousness in their definitions of invention. Obviousness is only found in the opposition and revocation stages of the process. New Zealand Patents Act 1953, s 21(1)(e) and s 41(1)(f) respectively. Obviousness is in the definition of invention under the Australian Patents Act 1990 and the New Zealand Patents Draft Bill 2004 Cl 13(a), and the United Kingdom Patents Act 1977, under which the United Kingdom Aktiebolaget was tried. 


\section{A Something More than Mere Novelty}

Novelty is a relatively simple matter to construe in comparison to the notion of obviousness. Novelty is determined quantitatively, in that all that is required is that it be different to the prior art. Obviousness is a qualitative evaluation, which assesses the extent of difference between the invention and the prior art, and whether the difference is sufficient. ${ }^{20}$ The non-obviousness standard is used "to distinguish patent-worthy inventions from routine or slight advances to the prior art that do not require a patent as an incentive." 21

Without the standard, there would be an increase in patent applications and grants for every incremental advance. The restricted competition that would arise would put an unfair burden on society, as the award from society would not be proportional to the benefit it receives in the small advance. ${ }^{22}$ It has been argued that the development of the obviousness standard by the courts, towards the end of the nineteenth century, was recognition of such public policy factors. ${ }^{23}$ It has also been suggested that the non-obviousness standard encourages research into more speculative and risky areas, that otherwise would not be attempted. ${ }^{24}$

\section{B Lockean Labour Theory}

The Lockean labour theory is used to justify having a private property interest. ${ }^{25}$ According to Locke, God created people with the main end of survival. As the end is set by God, people have a right to the end through the means of life, liberty, health and property. These are natural rights, in that they are rights humans equally have in a state of nature before the introduction of civil government. Locke holds that God gave the earth to all people in common and people have a property in their own person. Thus, when a person takes something from the common, and does work to it, through their work it becomes their property because everyone owns their labour. ${ }^{26}$

20 Lionel Bentley and Brad Sherman Intellectual Property Law (2 ed, Oxford University Press, New York, 2004) 470. Varu Chilakamarri "Structural Nonobviousness: How Inventiveness is Lost in the Discovery" (2005) 10 Va JL \& Tech 7, para 20.

21 Rebecca S Eisenberg "Obvious to Whom? Evaluating Inventions from the Perspective of PHOSITA" (2004) 19 Berk Tech LJ 885, 886.

22 Ibid, 887.

23 Griffiths, above n 15, 162.

24 Bentley and Sherman, above n 20, 470.

25 Chisum and others, above $\mathrm{n} 2,43$.

26 Ibid, 44. 
There are two main interpretations of the theory. The first is that labour itself should be rewarded because labour is unpleasant and people must be motivated to perform it. The second is that society should reward people for labour that adds value to something that benefits others. In this second interpretation it is not the labour that deserves reward, but the social value created. ${ }^{27}$

Obviousness limits the granting of patents for mere labour, as its criteria require that the benefit be of significance and not easily discernible from available information. This means that obviousness measures the value-added, with its purpose to award work that benefits society. Current patent systems, therefore, favour the second interpretation of the Lockean labour theory, with the systems currently protecting informational value-added over physical benefits, as is discussed further below. ${ }^{28}$

\section{VALIDITY OF OBVIOUSNESS IN LIGHT OF THE AKTIEBOLAGET (LOSEC) CASES}

\section{A Background of the Aktiebolaget (Losec) Cases}

Aktiebolaget Hässle ${ }^{29}$ owned two patents regarding Losec, a drug to cure stomach ulcers. One was for the active compound in Losec. ${ }^{30}$ For the active compound to fulfill its purpose it must reach the intestines. This means that it must first pass through the stomach, but as the active compound degrades on contact with mild acid, it can not do so without protection, as it would be degraded by stomach acid. Thus, Aktiebolaget also had a patent for the delivery of the active compound. This was a three-layered drug, consisting of the active compound at the core encapsulated by an intermediate layer followed by an outer enteric coating. Enteric coatings were well known of at the time, but being acidic, an enteric coating by itself would react with the acid-sensitive compound. An intermediate layer was introduced between the active core and the enteric layer as a physical and chemical buffer, and was claimed to be the inventive step. ${ }^{31}$

27 Ibid, 46. Excerpt from Justin Hughes "The Philosophy of Intellectual Property" (1988) 77 Geo LJ 287, 296330

28 See Part V C Removal of Obviousness: Are Novelty and Utility Sufficient?

29 Sometime called Astra, as they are members of the Astra pharmaceutical group based in Sweden.

30 The pharmaceutical name of the active compound is Omeprazole. Losec is the name of the drug made from Omeprazole in its delivery form.

31 See Cairnstores Limited, Generics (UK) Limited v Aktiebolaget Hässle [2002] EWHC 309, paras 1-2 (Ch) Laddie J; Aktiebolaget Hässle v Alphapharm Pty Ltd (2002) 212 CLR 411, para 1 Gleeson CJ, Gaudron, Gummow and Hayne JJ; Novartis New Zealand Ltd v Aktiebolaget Hassle [2004] 2 NZLR 721, para 3-4 (CA) Blanchard J for the Court. 
In all cases to be discussed the patent for the active compound had expired, but the formulation patent had not. This meant that generic companies were free to make drugs from the active compound, so long as they did not infringe on the remaining formulation patent by using the threelayered delivery system. ${ }^{32}$ On expiry of the patent for the active compound, generic companies made drugs with it, but did so with the three-layered formulation. When accused of breaching the formulation patent, generic companies sought revocation, claiming that using the intermediate layer was obvious.

Losec is said to be one of the world's best selling drugs, with estimates that over £10-million worth of it is sold everyday. ${ }^{33}$ The Aktiebolaget cases were heard all over the world, ${ }^{34}$ and are interesting in the different interpretations that courts took to obviousness.

\section{B Subjective Opinion of the Judiciary}

It has been said that obviousness is "as fugitive, impalpable, wayward, and vague a phantom as exists in the whole paraphernalia of legal concepts". ${ }^{35}$ Issues arise as to how examiners and courts measure the difference between the prior art and the invention, and once this is determined, by what means they are then to assess whether the difference is sufficient for the invention to be to nonobvious. The factual nature of these inquiries, regardless of how many tests the courts create and purportedly adhere to, will require some amount of subjective analysis, ${ }^{36}$ as obviousness is "an imaginary mental state". ${ }^{37}$ This makes obviousness a judgment-call and so highly unpredictable. ${ }^{38}$

In the New Zealand Aktiebolaget case, Blanchard J stated that obviousness is a question of fact that is to be determined by the evidence put before the court. His Honour stated that: ${ }^{39}$

32 Novartis New Zealand Ltd v Aktiebolaget Hassle, ibid, para 3-4 Blanchard J for the Court.

33 Antony Rumboll "Patents: Revocation of Patent Covering World's Best Selling Drug" (2002) 24(7) EIPR N116, N116.

34 Including in the United States of America, Canada, South Africa, Norway, Israel and the European Patents Office.

35 Harries v Air King Products Co (1950) 183 F 2d 158, 162 (2d Cir) Chief Judge Learned Hand, as quoted in Bentley and Sherman, above n 20, 469.

36 Grubb, above n 11, 58.

37 Paul M Janicke "On the Causes of Unpredictability of Federal Circuit Decisions in Patent Cases" (2005) 3 NW J Tech \& Intell Prop 93, para 6.

38 Ibid, para 8.

39 Novartis New Zealand Ltd v Aktiebolaget Hassle, above n 31, para 33 Blanchard J for the Court (emphasis added). Astra is the pharmaceutical group to which Aktiebolaget Hässle is attached. 
It cannot be assumed that in New Zealand the evidence for Astra will be the same as it was in England, where it did not persuade ... [D]ifferent evidence concerning obviousness can lead to a different result in relation to equivalent patents.

The use of the word "persuade" here is interesting. Blanchard $\mathrm{J}$ was referring not solely to the expert evidence given, but also its derivatives: submissions and any witness cross-examinations. The issue arises as to whether these tools of the judiciary are sufficient, as evidence should not so much "persuade" you to something, as point you to it. This indicates that some subjective opinion is required of the judiciary regarding expert evidence and its derivatives, as will be discussed further when looking at the person having ordinary skill in the art. ${ }^{40}$

Expert evidence being so heavily depended on as to lead to different results for equivalent patents is illustrated by the different Aktiebolaget cases. Such results are a concern, as whether there was actually an inventive step is the same in each jurisdiction, regardless of the expert evidence. The way in which the invention came about is identical, so to say that there was an inventive step in one jurisdiction, but not in another, cannot be correct. One jurisdiction must be wrong. This is particularly so under newer Patent Acts, by which the prior art being measured against should be the same in different jurisdictions, as the standard is worldwide. ${ }^{41}$ This creates uncertainty for the inventors and makes it difficult to ascertain where their patent will be protected. It shifts the focus away from proving the inventive step of invention itself and towards the evidence of the expert witnesses. This will be further addressed when looking at the objective nature of obviousness. ${ }^{42}$

The Court of Appeal also stated that it is not able to treat expert evidence from other jurisdictions as evidence for the New Zealand court, ${ }^{43}$ but the court did not admonish Potter $\mathrm{J}$ (in her High Court judgment) for being influenced by the evidence of an expert (Dr Marshall) from the Australian case. ${ }^{44}$ They instead found that she came to the right conclusion. This apparent contradiction is indicative of a conclusion first, reasoning second approach. It appears as though the judges want to grant an injunction, and so allowed the influence of favourable evidence, even though they stated that they could not look at.

40 See Part III C 1 Defining and finding the notional person.

41 The Australian Patents Act 1990 and United Kingdom Patents Act 1977 have an absolute prior art, as opposed to the older and current New Zealand Acts which have a local standard. The New Zealand Drafts Patent Act 2004 has an absolute standard for obviousness (cl 7).

42 See Part III F Objective Nature of the Inquiry.

43 Novartis NZ Ltd v Aktiebolaget Hassle, above n 31, para 29 Blanchard J for the Court.

44 Ibid, para 33 Blanchard J for the Court. 
It is arguable that in complex cases legal reasoning often works backwards from the decision to the rule, whereby the court justifies the decision it desires. ${ }^{45}$ Judicial intuition is said to be inescapable. ${ }^{46}$ The problem with judicial intuition is that intuitions can be wrong, particularly when it comes to such matters as the obviousness of complex technology. Even if they are made on prior experience, the judicial experience is not the experience obviousness is supposed to be assessed on.

Insufficient appropriate experience resulting in having to use one's subjective opinion is particularly apparent when considering any decision that must be made relating to the person having ordinary skill in the art.

\section{Who is the Person Having Ordinary Skill in the Art?}

According to the Windsurfing test the person to whom the invention must be non-obvious is a person skilled in the art, who is competent, but with no imagination or inventive capability. This person is an important reference point for both the factual determination of the invention in relation to the prior art, and analysis of obviousness. ${ }^{47}$

\section{Defining and finding the notional person}

The notional person can vary from case to case. In some situations the ordinary person in the field may be someone of average qualifications, but in highly specialised areas the ordinary person would be a team of highly qualified researchers. A lack of imagination is imputed to the notional person. ${ }^{48}$ This is to make the test workable. If the notional person had inventive capabilities the standard would be too high, as the test would be looking for a level of inventiveness above normal inventiveness. This would raise issues of what the normal inventiveness is within that group of notional people. However, the problem with removing inventive capabilities is that it is a fiction to say that such a highly qualified team is competent, but not imaginative, when the object of their employment is to do research and invent. ${ }^{49}$

For example, the High Court of Australia supported the trial judge's description of the notional person as a person or team experienced in formulating drugs for therapeutic use, highly qualified as pharmaceutical chemists with a demonstrated capacity for original research, but is not particularly

45 R George Wright "The Role of Judicial Intuition in Decisionmaking" (2006) 42 Hous L Rev 1381, 1414. See also Janicke, above n 37, para 17.

46 Ibid, 1385.

47 Griffiths, above n 15, 171 .

48 Aktiebolaget Hässle v Alphapharm Pty Ltd, above n 31, para 30 Gleeson CJ, Gaudron, Gummow and Hayne JJ. See also Grubb, above n 11, 59 .

49 Grubb, ibid, 59 
imaginative or inventive. ${ }^{50}$ This person cannot exist, as you cannot have someone who can do original research, but is unimaginative. This can result in the use of a less than ordinary skilled person in the art, and theoretically make it easier to obtain or protect a patent. ${ }^{51}$

In his dissent Kirby $\mathrm{J}$ stated that there are: ${ }^{52}$

[D]ifficulties inherent in constructing the fictitious worker in a field such as pharmaceutical formulation

... The process has introduced so many layers of obscurity that there is now a real danger of entering upon 'a degree of unreality ... going well beyond unreasonable hypothesis'...

It is even somewhat circular that the means by which inventiveness is assessed is by the ordinary person in the art, but we ascertain that person by looking for someone who would not be able to do something inventive. ${ }^{53}$

In his decision in the United Kingdom, Laddie $\mathrm{J}$ relied heavily on expert witnesses, particularly favouring the "dispassionate expert testimony" of the claimant's witness, Dr Rue. ${ }^{54}$ Laddie J was, however, highly critical of Aktiebolaget's witness Dr Rees, finding he was "acting as an advocate for the defendant's case", ${ }^{55}$ and favoured Dr Rue over Dr Rees on every material point.

Aktiebolaget argued that the claimant's witness, Dr Rue, did not have the relevant expertise to be a reliable witness, as he did not have any direct experience with enteric coatings. ${ }^{56}$ Laddie J rejected this claim, finding that at the time few people in the field had experience in enteric coating, although it was well known of and taught at undergraduate level; that the patent claim did not suggest anything special about the enteric coating; and that Aktiebolaget's witness, Dr Rees, had no such experience when he was put in charge of an enteric coating project (different from that for Losec and not for Aktiebolaget). ${ }^{57}$

50 Aktiebolaget Hässle v Alphapharm Pty Ltd, above n 31, para 30 Gleeson CJ, Gaudron, Gummow and Hayne JJ.

51 Eisenberg, above n 21, 892.

52 Aktiebolaget Hässle v Alphapharm Pty Ltd, above n 31, para 150 Kirby J, quoting Lubrizol (2000) 106 FCR 214, 236.

53 Eisenberg, above n 21, 892.

54 Rumboll, above n 33, N117.

55 Cairnstores Limited, Generics (UK) Limited v Aktiebolaget Hässle, above n 31, para 24 Laddie J.

56 Ibid, para 21 Laddie J.

57 Ibid, para 22 Laddie J, 
Laddie J made his findings on Dr Rue's appropriateness based on expert witness given to him by Dr Rue. If not for Dr Rue's evidence, his Honour would not have concluded that enteric coatings were well known of and taught at undergraduate level. Laddie J's reasoning that only a few people had actual experience with enteric coating, so the ordinary person in the field would not, could also be said to be flawed. That only a few had actual experience could mean that it was a narrow field of art, and by allowing Dr Rue as a witness Laddie $\mathrm{J}$ incorrectly widened the field of art to include those who had never done enteric coating. This shows the important effect that the defining of the field can have. If it had been defined narrowly, Dr Rue would most likely have been outside of the field, would not have been able to act as an expert witness, and the outcome of the case could have been very different.

His Honour's second reason that the claim did not suggest anything special about the enteric coating, inferred that it was not contentious, so Dr Rue did not have to be a specialist on enteric coatings. But a main issue in his judgment (dealt with in thirty-five paragraphs) was whether it was obvious to determine if the inner core ingredient interacted with the enteric coating. ${ }^{58}$ Laddie J's third reason is also not relevant, as Dr Rees' experience when he was first employed for a separate enteric coating project is not related to his ability as a witness at the time of the trial.

This shows a clear problem of where the line should be drawn between the ordinary notional worker and someone under or over qualified. It must be tempting for parties trying to show obviousness to use above ordinarily qualified experts to testify obviousness. ${ }^{59}$ Although it may be feasible for the Patent Office examiners (who usually have a background in research), to assess whether the expert is of an ordinary level, the means by which the courts are supposed to measure the appropriate level of expertise are more controversial. These are the use of cross-examination and counsel's submission, both of which require a high degree of dependence on the witnesses and counsel, and are inadequate as they result in the courts having to be persuaded or swayed one way or the other. There are some jurisdictions that use specialised or expert judges, such as Laddie J. This however does not seem to have helped in Aktiebolaget.

\section{Different views of people having ordinary skill in the art}

The problem with the factual nature of the inquiry is that any two reasonable notional people could easily come to different conclusions. ${ }^{60}$ This is demonstrated by the fact that both parties, in all three Aktiebolaget cases discussed, each have experts claiming to be people having ordinary skills in the art.

58 Ibid, para 33-68 Laddie J.

59 Grubb, above n 11, 59.

60 Bentley and Sherman, above n 20, 470. 
Laddie J's judgment was based almost entirely on expert opinion. His Honour preferred the plaintiff's witness and so found for the plaintiff, even though Aktiebolaget used the same expert (Dr Rees) as they did in the Australia, where their patent was upheld in the High Court.

The divergence between Laddie $\mathrm{J}$ and the High Court of Australia indicates the importance of the person having ordinary skill in the art, or lack thereof. The only way courts can deal with there being conflicting experts, and thus no one expert opinion, is by picking which expert they prefer or believe more. Thus, it becomes the judge's opinion, rather than the expert opinion, and leads to unpredictability in cases involving obviousness. The result is that the courts only consult the notional person on the scope, content and meaning of the prior art, but not on whether it actually would have been obvious at the time in light of the prior art. ${ }^{61}$ This the courts decide themselves. ${ }^{62}$

One of the expert witnesses in Australia, Dr Marshall, was given varying instructions from the generic company to create a viable delivery system for the active compound, without being shown the patent. He was unable to do so, despite having been given the opportunity to submit six different reports. ${ }^{63}$

Interestingly, Callinan $\mathrm{J}$ actually commented on the fact that the lower Full Court spent over fifty paragraphs going into great depths about all the experts' evidence to find for the generic company, but did not discuss Dr Marshall's evidence, which Callinan J (and the majority) found favoured Aktiebolaget. ${ }^{64}$ Lehane J, the trial judge, even found that Dr Marshall's evidence favoured the generic company. Finding that although he did not actually manage to formulate Losec, he came close, indicating obviousness. ${ }^{65}$

It is submitted that Dr Marshall's "invention duplication exercise" evidence differed from the other experts', as it was not his point of view and so did not require any extrapolation. His evidence was not whether he thought the claimed inventive step was obvious, thus rather than being merely persuasive, his inability to replicate the invention should be evidence in itself of non-obviousness. Because of this, "invention duplication exercise" evidence should not require the court to choose an expert.

61 Eisenberg, above n 21, 888 .

62 Ibid, 889.

63 Aktiebolaget Hässle v Alphapharm Pty Ltd, above n 31, para 28 Gleeson CJ, Gaudron, Gummow and Hayne JJ.

64 Ibid, para 199 Callinan J.

65 Aktiebolaget Hässle v Alphapharm Pty Ltd (1999) 44 IPR 593, 616-617, para 83 (FCA) Lehane J. 
The nature of the inquiry is objective, ${ }^{66}$ such that Laddie $\mathrm{J}$ also relied on textbook references to show what the ordinary person in the art would have done. ${ }^{67}$ This is strange, because it seems that he equates the textbook references with the person having the ordinary skill in the art. Laddie $\mathrm{J}$ in fact preferred the evidence of the textbook references over that of Dr Rees, who was actually a person in the field, and so arguably a better objective measure. There is no distinction in his judgment between documents and evidence of prior art, and evidence as to what the ordinary person in the field actually would have done.

That something may be taught at undergraduate level, ${ }^{68}$ and may be in textbooks, is useful in forming the prior art the ordinary person in the field should know, but it is not the same as what may actually be done in practice. This may be due to such limits as time, cost, labour demand, and even the memory of the researcher, as one can not be expected to remember everything. In some cases, it may be that the notional person knows more than what is in textbooks, as they may only make reference to basic materials. It is also possible that the textbooks are more detailed than what the notional person knows. This is very much dependent of how specialised the textbook is.

Both textbooks and Dr Rees offer objective evidence. The existence of two opposing views requires that the courts chose the view they find more persuasive. Laddie $\mathrm{J}$, in choosing to favour the textbooks over Dr Rees, was asserting his own subjective opinion. The result is that the objective test removes the subjective process that took place and replaces it with the subjective opinion of the examiner or judge as to whether there was an inventive step. The use of "invention duplication exercise" evidence would show what an actual person in the field would have done, and would not require a choice to be made between witnesses, thus removing this problem.

Different judges favouring different expert witnesses or textbooks, and three courts interpreting the same witness to be saying three different things, creates a high level of uncertainty. Although much of this uncertainty is created in assessing the notional person's level of skill, it is compounded by also having to determine their knowledge level, as seen by Laddie J's equating of textbooks and the notional person.

66 See Part III F Objective Nature of the Inquiry.

67 Cairnstores Limited, Generics (UK) Limited v Aktiebolaget Hässle, above n 31, paras 46, 47, 55, 57, 67, 70, and 73 Laddie J.

68 Ibid, para 22 Laddie J. 


\section{What Does the Person Having Ordinary Skill in the Art Know?}

\section{Extent of knowledge}

Aktiebolaget Australia was decided under the 1952 Act, ${ }^{69}$ which states that the inventive step must be measured against what was "known or used". ${ }^{70}$ This is compared to the United Kingdom case, where one must have regard to "any matter which forms part of the state of the art", ${ }^{71}$ and is made available to the public. ${ }^{72}$

The United Kingdom prior art is restricted by the fact that it is judged through the eyes of a person skilled in the art, such that emphasis may be put on certain pieces of prior art and some may be dismissed. ${ }^{73}$ The relevant prior art is the common general knowledge, as termed in the Windsurfing test.

In the Australian case Minnesota Mining and Manufacturing it was held that what was known or used had to be part of the general knowledge of those in the field. ${ }^{74}$ This meant that, like in the United Kingdom, not all publications had to be looked at as part of the prior art, even if accessible in Australia. ${ }^{75}$

The problem with this is that it requires much speculation. In addressing what the notional person should know the courts are attributing qualities to them. ${ }^{76}$ For example, that the notional researcher does not look at patent specifications, ${ }^{77}$ or they do not work in large firms. ${ }^{78}$ It is difficult to distinguish between knowledge that is commonly known and that which is only known to a few. ${ }^{79}$ This can be seen by the different approaches taken by the trial judge and the High Court

\footnotetext{
69 As opposed to the newer Australian Patents Act 1990.

70 Australian Patents Act 1952, s 100(1)(e).

71 United Kingdom Patents Act 1977, s 3.

72 Ibid, s 2(2)

73 Bentley and Sherman, above n 20, 475

74 Minnesota Mining and Manufacturing Company v Beiersdorf (Australia) Ltd (1980) 144 CLR 253, 294-295 Aickin J. Like Aktiebolaget this was tried under the Patents Act 1952.

75 Aktiebolaget Hässle v Alphapharm Pty Ltd, above n 31, para 57 Gleeson CJ, Gaudron, Gummow and Hayne JJ.

76 Griffiths, above n 15,171

77 See Minnesota Mining and Manufacturing v Beiersdorf (Australia) Ltd, above n 74.

78 See Beloit Technologies Inc v Valmet Paper Machinery Inc [1997] RPC 489 (EWCA)

79 Griffiths, above n 15, 172.
} 
in Aktiebolaget. Where Lehane $\mathrm{J}$ found that the common knowledge included what could be learnt from a routine literature search, if the ordinary person in the art would have done one, ${ }^{80}$ the High Court found that although the information was accessible, it was not assimilated into common general knowledge, and so not a part of the relevant prior art. ${ }^{81}$

The approach of assuming all matter is relevant prior art is more certain, as it does not require analysis of what might or might not have been known as general knowledge to those in the field. The concept of common general knowledge is also not required by either statute. The term "known or used" could incorporate routine literature searches, and should if it is normal practice in a field to do so. To assume that researchers will not perform literature searches before commencing an experiment is artificial. ${ }^{82} \mathrm{~A}$ basic (if not in depth) literature search would be done initially to see if anyone had done the research, or something similar to it to get extra ideas or assistance. Even seeing what has not worked is helpful. Once a project is underway, literature searches would also be performed if any problems were hit to try and find a solution. Researchers do not work in a vacuum, free from all other research.

The concept of common general knowledge also does not sit with the statutory wording in the United Kingdom, where it states "any matter". The result is that the prior art is different for assessing novelty and obviousness, despite the same wording in statute. The justification for this difference could be the relative importance of obviousness compared to novelty. As obviousness is meant to be a higher standard, it seems counter-intuitive that less prior art is considered when looking at obviousness than when assessing novelty. But, in deciding whether something is novel, all prior art must be assessed for the quantification to be workable. It is important that, at some stage, all prior art is considered. However, in deciding whether something is obvious the notional person would not consider everything, as it may not be reasonable or realistic and would be an insurmountable standard.

Under the Australian 1990 Act, obviousness is assessed "in the light of the common general knowledge". ${ }^{83}$ This is a legislating of the common law, which means it is likely that obviousness will be assessed the same way under the 1990 Act as the 1952 Act in Aktiebolaget.

The use of "invention duplication exercise" evidence would avoid having to decide what the notional person should know. Giving a notional person the problem and asking him to find a

80 Aktiebolaget Hässle v Alphapharm Pty Ltd, above n 65, 629, para 118 Lehane J.

81 Aktiebolaget Hässle v Alphapharm Pty Ltd, above n 31, para 57 Gleeson CJ, Gaudron, Gummow and Hayne $\mathrm{JJ}$.

82 Ibid, paras 167 and 176 Kirby J.

83 Australian Patents Act 1990, s 7(2). 
solution, as if they were doing the research, would indicate what the industry norm was. This would also apply to mosaicing.

\section{2 'Mosaics'}

Combining different pieces of prior art can be used to show obviousness under the 1977 United Kingdom Act, as long as it would have been obvious to an ordinary person skilled in the art to consider them in association. ${ }^{84}$ Mosaics were not allowed under the 1952 Australian Act, ${ }^{85}$ so the notional person in Australia for Aktiebolaget knew less than their counterpart in the United Kingdom.

Mosaics are allowed under the 1990 Act, provided the skilled addressee would be "reasonably expected" to do so. ${ }^{86}$ This makes the Australian hypothetical person under the 1990 Act potentially more like those in the actual field than the person in the United Kingdom. The phrase "reasonably expected" infers that it should reflect those actually in the field. ${ }^{87}$ This, however, has not occurred, as the Australian cases have read "reasonable" as meaning could "be put together by an unimaginative man with no inventive capacity", as in the United Kingdom. ${ }^{88}$

Mosaicing has been criticised for altering the state of the art, ${ }^{89}$ making it easier to succumb to hindsight. It is relatively simple, with the benefit of hindsight, to put together different documents and claim obviousness. ${ }^{90}$

\section{E Assessing the Inventive Step - Inevitability of Hindsight}

Once the notional person and their knowledge level have been defined, it is then asked if there was an inventive step. In doing this, hindsight is a trap that the courts are always wary of falling into. ${ }^{91}$ It is often easy to construct an invention with the benefit of hindsight, particularly when one

84 Griffiths, above n 15, 181.

85 As held in Minnesota Mining and Manufacturing Company v Beiersdorf (Australia) Ltd, above n 74.

86 Australian Patents Act 1990, s 7(3), as substituted by the Patents Amendment Act 2001.

87 Kim O'Connell and Julian Cooke "Australia: A Patentee's Paradise" (2003) 25(10) EIPR 481, 484.

88 See Tidy Tea Ltd v Unilever Australia Ltd (1995) 32 IPR 405, 414 (FCA) Burchett J; Stack v Brisbane City Council [1999] FCA 1279, para 160 Cooper J; both of which followed the United Kingdom: Technographic Printed Cirtcuits Ltd v Mills \& Rockley (Electronics) Ltd [1972] RPC 346, 355 (HL(E)) Lord Reid.

89 Griffiths, above n 15, 182.

90 Grubb, above n 11, 64-65.

91 Aktiebolaget Hässle v Alphapharm Pty Ltd, above n 31, para 21 Gleeson CJ, Gaudron, Gummow and Hayne JJ. 
has seen the particular specification. ${ }^{92}$ This does not automatically mean that the process was obvious. ${ }^{93}$

In the United Kingdom Aktiebolaget, Laddie J used a "problem and solution" approach with an obvious to try test. He asked whether (A) the skilled worker would realise that a problem existed; 94 and (B) if the skilled worker would think of trying to solve the problem the way the patentees did, because it was obvious or worthwhile to try. ${ }^{95}$ The High Court of Australia, in Aktiebolaget, rejected both the problem and solution approach and the obvious to try approach taken by the United Kingdom. ${ }^{96}$

\section{Problem and solution approach}

This approach was adopted to evaluate whether there was an inventive step in light of the Windsurfing test. It is a combination of the first and third steps, looked at as a problem or deficiency arising from the prior art to be solved by the invention. The second and fourth steps are then looked at to assess whether the ordinary person in the art would have found the solution obvious.

The High Court of Australia found that using the problem and solution approach meant looking at the assumed result as a starting point, which leads to the use of hindsight when examining the evidence. ${ }^{97}$ In Aktiebolaget the problem set out by Laddie $\mathrm{J}$ was the problem that the researchers were trying to solve, this being a suitable dosage form of the compound. But often the problem set out is not the problem the researcher was trying to solve, making the general test artificial. ${ }^{98}$ In some situations there may have been no problem in mind at all. ${ }^{99}$

In assessing the claimed inventive step, the patent specification is not supposed to be considered, ${ }^{100}$ but once in one's mind it is difficult, if not impossible, to expel it while considering

92 Eisenberg, above n 21, 889-891.

93 Grubb, above n 11, 59.

94 Cairnstores Limited, Generics (UK) Limited v Aktiebolaget Hässle, above n 31, para 32-33 Laddie J.

95 Ibid, para 68-69 Laddie J.

96 Aktiebolaget Hässle v Alphapharm Pty Ltd, above n 31, para 72 Gleeson CJ, Gaudron, Gummow and Hayne $\mathrm{JJ}$.

97 Ibid, para 60 Gleeson CJ, Gaudron, Gummow and Hayne JJ.

Grubb, above n 11, 60 .

99 Bentley and Sherman, above n 20, 472.

100 See Minnesota Mining and Manufacturing Company v Tyco Electronics Pty (2002) 56 IPR 248, para 45 (FCA) Heerey, Emmett and Dowsett JJ, where it was found that "to give the patent to a prospective witness is tantamount to leading the witness." 
obviousness. For this reason, the Australian majority favoured Dr Marshall's evidence, as he was the only generic company expert to not have been shown the formulation patent. ${ }^{101}$ That "a skilled practitioner, Dr Marshall, armed with suggestions from the respondent, and with the desired result identified for him, was unable to replicate the appellants' pill" was evidence of non-obviousness. ${ }^{102}$ It showed that he was still weighing up all the possible options that may or may not have worked. ${ }^{103}$

Dr Marshall was given a problem and asked to find a solution for it. This is different than the problem and solution approach, as he was not given the solution first and asked for his view on its obviousness. Therefore, it is submitted that "invention duplication exercise" evidence also avoids concerns of hindsight.

\section{2 "Obvious to try"}

In rejecting the obvious to try approach used by the United Kingdom, the Australian High Court found that one has to look at whether the invention itself is obvious, not whether a particular avenue of research was obvious to try. ${ }^{104}$ The divergence between the two jurisdictions was found to be due to the "Europeanisation" of the British law. ${ }^{105}$

The Australian Court preferred the approach taken in the United States, where the obvious to try approach has also been rejected because: ${ }^{106}$

$[T]$ here is usually an element of 'obviousness to try' in any research endeavour, that it is not undertaken with complete blindness but rather with some semblance of a chance of success ... [P]atentability determinations based on that as the test would not only be contrary to statute but result in a marked deterioration of the entire patent system as an incentive to invest ...

The obvious to try approach is too broad and too low a standard that does not take into account how research is actually done. By focusing on the area of research, rather than the invention, the approach misses that the inventiveness can lie in the invention and choosing which path to take, rather than the inventiveness of the path itself. In other words, the method used may not be new or inventive, but thinking of using the method may be non-obvious.

101 Aktiebolaget Hässle v Alphapharm Pty Ltd, above n 31, para 28 Gleeson CJ, Gaudron, Gummow and Hayne JJ.

102 Ibid, para 192 Callinan J.

103 Ibid, para 193 Callinan J.

104 Ibid, para 72 Gleeson CJ, Gaudron, Gummow and Hayne JJ.

105 Ibid, para 48 Gleeson CJ, Gaudron, Gummow and Hayne JJ.

106 Application of Tomlinson (1966) 363 F 2d 928, 931 (Cust \& Pat App) Judge Rich. 
The New Zealand Aktiebolaget did not address the obvious to try approach, but in Peterson Portable Sawing Systems the Court of Appeal, and the Supreme Court, in its first intellectual property case, followed Australia in dismissing it. ${ }^{107}$ Anderson $\mathrm{P}$ stated that "[i]t seems to add little to the technique of ascertaining obviousness. Anything might be worth a try ... but inventiveness may lie in deciding what to try." 108

It is a deceptively simple test that has the potential to mask a large amount of hindsight, as many things may be obvious to try with the benefit of hindsight. It thereby lowers the threshold of obviousness. ${ }^{109}$

The approach also begs the question that if it were so obvious to try, why did no one else try it? Obviousness has to be tied to something. It can not just be assessed in itself. Barker J stated that: ${ }^{110}$

... the question must tie in the relationship or concept of obviousness to something; obvious to try for what? worthwhile to try for what? ... It is not possible to speak of a claim being obvious in vacuo. It must be obvious to a particular end.

The opposing argument could be made that no one else tried it because it was too simple or obvious. But this, despite being a defense for the obvious to try test, is a contradiction to it. If it is argued that the solution was too simple to be considered worthwhile to try, it can not then be said to be so simple as to be worthwhile to try, and thus obvious.

The United Kingdom has subsequently limited the application of the approach in Saint-Gobain v Fusion Provida, where Jacob LJ stated that the test "really only works where it is more-or-less selfevident that what is being tested ought to work". ${ }^{111}$

\section{Seemingly simple solutions}

A general problem with the test of obviousness, and particularly the obvious to try approach, is that it is easy to view a simple answer to a complex problem as requiring no inventive step. In hindsight it would be difficult to see how such a simple solution could not have been obvious to the

107 See Peterson Portable Sawing Systems Ltd v Lucas [2005] BCL 288 (CA); Peterson Sawing Systems Ltd (in liq) v Lucas [2006] 3 NZLR 721 (SC).

108 Ibid (CA), para 85 Anderson P for the Court.

109 Andrew Brown "Peterson Portable Sawing Systems Ltd v Lucas" www.andrewbrown.co.nz (accessed 26 June 2007).

110 Beecham v Bristol Myers (No 2) [1980] 1 NZLR 192, 249 (HC) Barker J (emphasis in original).

111 Saint-Gobain v Fusion Provida [2005] EWCA Civ 177, para 35 Jacob LJ. 
ordinary person in the art. ${ }^{112}$ However, it is often the most simple of solutions that work best or are the most difficult to find.

In Aktiebolaget the formulation of the three layered tablet is seemingly simple and not requiring inventiveness, particularly in hindsight. It seems obvious that if the drug reacts with stomach acids that it has to get past, one should coat it, and if it reacts with the coating, then one should use a different coating or an intermediate layer. The issue here is the same as that with the problem and solution approach. While thinking about whether it would have been obvious if "I were in the shoes of the ordinary person in the art at that time" examiners can not help but have the actual solution in mind, so are never actually in those shoes.

The use of "invention duplication exercise" evidence would eliminate the issue of seemingly simple solutions being obvious in hindsight, as asking a witness to solve a problem without first showing them the solution would indicate whether the solution was in fact obvious to try, or only seemingly obvious or simple in hindsight.

\section{E Objective Nature of the Inquiry}

Although obviousness is a qualitative inquiry, there is no requirement as to how large the inventive step must be to be sufficient. ${ }^{113}$ It is meant to be a completely objective test, and so does not look at how the inventive process actually took place. ${ }^{114}$ Whether the invention was "a result of planned research, a flash of inspiration or even pure chance is not relevant" when assessing obviousness. ${ }^{115}$ The awarding of a patent is not based on what actual work took place, but instead only looks at the end product and deduces from it if sufficient work has been done. Thus, current patent systems support the interpretation of the Lockean labour theory that society should reward labour that adds value and benefits society, rather than the labour itself. ${ }^{116}$

\section{The problem with only awarding unexpected results}

Only allowing objective evidence means that it is only unexpected results that can clearly be found to be non-obvious. It is difficult to envisage a situation where the end result is foreseeable, but non-obvious. This is problematic when one considers that there is a fine line between an unexpected result and an un-patentable discovery.

112 Cole, above n 17, 267.

113 Grubb, above n 11, 59.

114 Bentley and Sherman, above n 20, 473.

115 Grubb, above n 11, 59.

116 See Part II B Lockean Labour Theory. 
The High Court of Australia in Aktiebolaget quoted In re O'Farrell to justify rejecting the obvious to try approach: ${ }^{117}$

[F]or many inventions that seem quite obvious, there is no absolute predictability of success until the invention is reduced to practice. There is always at least a possibility of unexpected results, that would then provide an objective basis for showing that the invention, although apparently obvious, was in law nonobvious.

An example of such a situation would be that in the United Kingdom it was found that the use of a three layered tablet was obvious to try. But, if in the process of adding the two extra layers the compound became unexpectedly more active because of favourable interactions with the coatings, it could be found to be non-obvious.

In practice the same potentially inventive step has been taken in both situations, and the same amount of work has been done. The awarding of patents for unexpected results is, therefore, only rewarding the value-added to the field rather than the labour itself. It is by chance whether or not a researcher comes across an unexpected result. Science is often luck and that is why some discoveries are not obvious. Often, it is mistakes that lead to new discoveries. The examiners and courts are effectively awarding for something that researchers have no control over, such that the award becomes dependent on the skill of the patent application's drafter in making the discovery look not like a discovery, but an invention. However, the objective nature of the obvious inquiry does not allow the courts to address these factors.

In Beecham v Bristol-Myers Cooke J (as he was then) stated that "the pursuit of an obvious line of research ... may be held to culminate in an invention which is not obvious and does involve an inventive step, if a sufficiently distinctive advantage is discovered." 118

It seems counter-intuitive that an obvious line of research is not obvious if an unexpected result is discovered, but a non-obvious line of research is in law obvious if the obtained result is foreseeable. It is arguable that unexpected results are distinct from discoveries, as when the researcher came across the result they were looking for something, just not what they found. But accidental or unexpected results are more like discoveries than inventions when looked at from the view that the inventive step lies in the unexpected result.

That unexpected results may be more like discoveries is not to say that they should thereby be un-patentable, but to say that there was an inventive step is a legal fiction. The concept of

117 In re O'Farrell (1988) 853 F 2d 894, 903 (Fed Cir) Circuit Judge Rich, as quoted in Aktiebolaget Hässle v Alphapharm Pty Ltd, above n 31, para 74 Gleeson CJ, Gaudron, Gummow and Hayne JJ.

118 Beecham v Bristol-Myers Co [1981] 1 NZLR 600, 609 (CA) Cooke J for the Court (emphasis added). 
obviousness envisioned by Windsurfing does not fit these types of situations. If we take the example set out above, the inventive concept embodied in the invention would be the increased activity on coating. The prior art would consist of the properties of the compound itself, and the method of enteric coating. The differences between the prior art and the new invention would be the increased activity. If we then take the notional person with the common general knowledge, and ask if in light of the prior art would the differences be obvious, the answer of course will be no. An unexpected result could never really be said to be obvious, as the name implies.

Like with the problem and solution test, the objective focus on the unexpected result is equivalent to looking at a problem the researcher was never trying to solve. To be seen as deserving of a patent, unexpected results have to be looked at subjectively in terms of the actual steps taken and work done.

It could be argued that such an invention is held to be non-obvious because there is an assumption that it was only unexpected to the ordinary person in the art, but not to the researcher. But the issue would arise of how examiners and courts would distinguish between situations where the researcher expected the result, and where it was wholly unexpected. This would require subjective evidence, which is not allowed under the objective test.

Issues also arise when an invention is made that has some expected properties, and some unexpected. ${ }^{119}$

\section{ALTERNATIVE PROCESSES OF ASSESSING AN INVENTION}

\section{A Early Consultation with the Person Having Ordinary Skill in the Art}

Consultation with practitioners at an earlier stage in the process, such as pre-grant would give examiners the knowledge of current practitioners at the time of granting. ${ }^{120}$ Eisenberg suggested two mechanisms for this: a scientific advisory board or a peer review system.

The difficulty in assembling an advisory board is that Patents Offices consider a wide range of technologies, ${ }^{121}$ and as the notional person and their skill level is different in every situation an advisory board would not work. For both an advisory board and peer review, having to consult externally would slow down the process. ${ }^{122}$ It would also be expensive, which is hard to justify when it is often small decisions that they make, and many patents are never used, licensed or

119 Grubb, above n 11, 195.

120 Eisenberg, above n 21, 889.

121 Ibid, 902.

122 Ibid, 903. 
litigated. It would be difficult, if not impossible, to decide which patents would warrant a costly review. ${ }^{123}$ The use of current practitioners is also open to bias, as it would be hard to find a completely objective practitioner with no conflicts of interest. ${ }^{124}$ This is particularly so if they are current practitioners in the same industry as that of the patent application. ${ }^{125}$ Neither approach would help in determining who the ordinary person in the art is, nor would they address the issue that different people can interpret the same facts differently and that the same issues of hindsight would arise.

A good way of removing the hindsight and subjectivity required in the factual analysis would be to get "invention duplication exercise" evidence. This would be getting an ordinary person in the art to try and make the invention, without having seen the patent. However, this again would still require determination of the ordinary person in the field and be open to bias. It would also be expensive and not always justified in the pre-grant stage, thus its use could be confined to litigation proceedings.

In trying to reduce hindsight in expert witnesses there has been an increase in applications to the Federal Courts of Australia to require patentees to provide a statement of the inventive step said to be involved in the patent. ${ }^{126}$ This would put the onus on the patentee to prove inventiveness and help to remove later ambiguity. It would be like a statement of what the actual problem and solution was, but from the inventors rather than determined by the courts. ${ }^{127}$ Such a statement would still require ascertainment of whether the solution was obvious, but would assist in preparing nonleading questions to ask expert witnesses, and for obtaining "invention duplication exercise" evidence. The statement could not be given to the expert, as this would be leading the witness. ${ }^{128}$

\section{B Removal of Obviousness: Are Novelty and Utility Sufficient?}

It is questionable whether it matters if it was obvious to make a three layered tablet. Losec is still novel and has utility (or is useful). Its high sales indicate its benefit to society, such that its small contribution to the known prior art could be said to be irrelevant.

123 Ibid, 902.

124 Ibid.

125 Ibid, 904.

126 O'Connell and Cooke, above n 87, 485.

127 The EPC, r 27(1)(c) and r 33(2) requires that "the description should disclose the invention as claimed in such terms that the technical problem (even if not expressly stated as such) and its solution can be understood." This is different from the problem and solutions approach used by the United Kingdom, where the problem and solution are posed by the courts or examiners, rather than the patentee.

128 O'Connell and Cooke, above n 87, 485. 
As discussed above, ${ }^{129}$ the purpose of obviousness is to circumvent the unnecessary granting of patents to unworthy inventions. Quantitative novelty is in itself insufficient. The question then is whether the concept of utility is sufficiently ample, as a qualitative measure, such that obviousness is not required.

In 1825, Story $\mathrm{J}$ stated that if a combination "is new, if it is useful, if it has not been known or used before, it constitutes an invention". ${ }^{130}$ His Honour's rejection of the non-obvious standard was a declaration that novelty and utility were adequate requirements for patentability. ${ }^{131}$ This is because, like obviousness, utility is a measure of an invention's merits. ${ }^{132}$ As obviousness is the informational benefit of the quid pro quo, utility is the physical benefit of the invention itself.

The problem with ejecting obviousness is that it could result in granting patents for small increments to the prior knowledge. Neither novelty nor utility assess the level of the new information above the prior art. This could lead to piggy-backing on prior patents (either another researcher's or one's own), effectively extending the period of restricted competition. This would put a burden on society, who must put up with this for little increase in knowledge that could have arisen without a patent incentive. But the question then arises of what truly benefits society and its wants. As stated above, ${ }^{133}$ the patent system has shifted to favouring advances in knowledge rather than the benefits of the actual invention.

It is arguable that the majority of members of society would likely much rather suffer the burden of restricted competition for the actual physical benefits of an invention that many could potentially benefit from, than for a gain in knowledge that would only benefit a few. This would suggest that the patent system is not protecting the same interests that society values, when it is society who must bear the burden of a patent.

However, if patents could be gained for small increments, the encouragement for a higher level of innovation could be removed, deferring research from risky and speculative areas. Utility is also a low standard that is easily achieved. ${ }^{134}$ There is no requirement of how useful it has to be, only

129 See Part II A Something More than Mere Novelty.

130 Earle v Sawyer (1825) 9 F Cas 254, 257 (CCD Mass) Story J.

131 Edward C Walterschield "The Hotchkiss Unobviousness Standard: Early Judicial Activism in the Patent Law" (2005) 13 J Intell Prop L 103, 113.

132 N Scott Pierce "In Re Dane K Fisher: An Exercise in Utility" (2006) 6 J High Tech L 1, 1.

133 See Part I Introduction.

134 A patent may be revoked under s 41(1)(g) Patents Act 1953 on the basis that the invention is not useful. Fawcett $v$ Homan (1896) 13 RPC 398, 405 (EWCA) Lindley LJ stated that "[i]f an invention does what it is intended by the patentee to do and the end attained is itself useful, the invention is a useful invention." 
requiring that one of the invention's objectives is achieved. ${ }^{135}$ The utility requirement does not limit patentability to the same extent that obviousness does. An increase of grants would create more grey areas, wherein researchers would desist from investigating in fear of breaching a patent.

But in most cases, small increments of change are unlikely to create something that will be as highly useful to society and sell as well as Losec has. Therefore, researchers (and more importantly their funding sources) will still be encouraged to be innovative to make something highly useful and marketable, so that they can create something that will reap high monetary awards. The cost of getting a patent would also deter creators from getting patents for inventions that they do not expect to be useful enough to be worth patenting.

Even if there were a flood of patents granted for new inventions that add little to the prior art, the product still has to stand the test of the market. It may increase the likelihood of the creation reaching the market, but unless the invention is highly useful to society, society is unlikely to ever have to put up with any limit on competition. Such a situation may be no different to the current one, where many patents are granted for inventions that never make the market.

Under the Draft Patents Bill an invention is "useful if the invention has a specific, credible and substantial utility". ${ }^{136}$ The standard that must be reached under the Bill should be higher than the current standard of patentability. This is for two reasons. The first is because utility would be required for the invention to be patentable, and not just a measure for revocation. The second is the use of the word "substantial", which infers that it must be more useful than the current utility standard. Thus, the changes in the use of utility in the Bill would arguably support the removal of obviousness.

The awarding of patents for unexpected results when the steps taken were obvious also fits in well with a system where only novelty and utility must be satisfied. It would mean that one could qualify for a patent for doing something obvious, but making something valuable to society, regardless of any expected or unexpected results. It could even be said that the current awarding of patents for purely unexpected results from an obvious line of research is really only rewarding the utility of the invention, as this practice do not fit the conventional Windsurfing test.

It would also benefit researchers who are methodical in the way they work and try out every scenario. These researchers may not be doing anything non-obvious, but they are still working for

135 See Coopers Animal Health Australia Ltd v Western Stock Distributors Ltd (1986) 6 IPR 545 (FCA). The Australian Federal Court held that the utility of the invention claimed must be examined, not the invention described in the body of the specification.

136 New Zealand Draft Patents Bill 2004, cl 10 (emphasis added). 
results potentially beneficial to society. It does not make sense to deter researchers from doing something obvious if it could be of societal benefit.

In assessing whether an invention is patent worthy the Patents Office could look at the work done along with utility. For example, years taken, number of staff, hours spent. This would reward labour as well as adding value that benefits society. There is, however, the fear that superiority of resources would advantage some over others, ${ }^{137}$ and it would not cover flashes of genius or sudden inspiration, which obviousness seems to cover better. This would be very subjective and would unlikely assist any patent, obviousness or public policy objectives. There is a balancing between awarding researchers for the actual work they have done and awarding for making something that benefits society. The courts and the patent system favour the latter. In Aktiebolaget Australia Kirby J stated that "[i]t is not diligence and determination or the input of time, labour, skill and effort or the expenditure of resources that meet the criteria in the Act. Something more is needed". ${ }^{138}$

A system without obviousness would still be objective and fit into the second interpretation of the Lockean theory, as assessing utility would be like looking at the physical value-added to society, rather than the informational.

\section{CONCLUSION}

Under current patent processes obviousness is assessed via variations of the Windsurfing test. This process is inherently unpredictable at every stage because of the factual and qualitative nature of each inquiry. The notional person is pivotal both in determining the factual basis of the inquiry and in the evaluative stage of whether it was obvious. The Aktiebolaget cases have shown that determining who this person is, their background, skill level and what knowledge is normal for them to have access to, is problematic. These factors are not decided by someone currently in the art, but by examiners or courts. The person is nonetheless very influential towards the outcome of the case.

The factual nature of the inquiry means that reasonable notional people can easily come to different conclusions. The existence of opposing expert witnesses results in judges having to pick which expert they prefer. Thus, the expert opinion is replaced by the judge's opinion. This is particularly apparent in the Australian Aktiebolaget, where all three courts interpreted Dr Marshall's evidence differently.

Neither the Windsurfing test nor the additional problem and solutions approach tell us what quality is required for inventiveness in the evaluative step. The problem and solution and obvious to try approaches involve much hindsight, and still do not give a means by which to evaluate

137 Genentech Inc v Wellcome Foundation Inc (1988) 15 IPR 423, 526 (EWCA) Mustill LJ.

138 Aktiebolaget Hässle v Alphapharm Pty Ltd, above n 31, para 161 Kirby J. 
obviousness. The structure of such methods may assist in framing what we are trying to determine for obviousness, but inevitably result in still having to ask whether that was obvious. This evaluative question must always be answered by the examiners or judges, who may be guided by current persons in the art, but are themselves not.

Suggestions of bettering the approach usually involve earlier involvement of expert witnesses. It is submitted that "invention duplication exercise" evidence would be beneficial for the current obviousness standard, because it speaks for itself. However, it would be expensive and unlikely justified, but for litigation. Defining and finding the notional person would still be an issue.

One of the justifications of obviousness is that it limits granting patents for small increments in knowledge. It is arguable that obviousness is not required for this, as the cost of getting a patent for small increments in knowledge will hardly be worth it. This is unless the invention is highly useful and marketable, but it would be rare cases where minor changes will result in highly useful products. It is possible that in such cases, in terms of societal benefit, the high utility outweighs the small gain in information. Researchers would still be encouraged to research into speculative and risky areas, as it is there that they are more likely to find something highly useful and therefore marketable.

The current system rewards value-added to society, rather than pure labour. A system without obviousness could still do this, except it would look at the practical value-added through utility, rather than the informational value. Thus, the focus of the patent system would not have to be shifted. 